\title{
Does Board of Director's Characteristics Affect Firm Performance? Evidence from Malaysian Public Listed Companies
}

\author{
Siti Norwahida Shukeri ${ }^{1}$, Ong Wei Shin ${ }^{1}$ \& Mohd Shahidan Shaari ${ }^{1}$ \\ ${ }^{1}$ School of Business Innovation and Technopreneurship, University Malaysia Perlis, Malaysia \\ Correspondence: Siti Norwahida Shukeri, School of Business Innovation and Technopreneurship, University \\ Malaysia Perlis, Malaysia. E-mail: sitinorwahida@unimap.edu.my
}

Received: June 20, 2012

Accepted: July 19, 2012 Online Published: August 8, 2012

doi:10.5539/ibr.v5n9p120

URL: http://dx.doi.org/10.5539/ibr.v5n9p120

\begin{abstract}
The aim of this study is to answer the question: "do board characteristics affect firm performance?” There are six board of directors' characteristics being studied, including managerial ownership, board size, board independence, CEO duality, gender diversity and ethnic diversity. Return on Equity (ROE) is used as a measurement for firm financial performance. There are 300 Malaysian public listed companies being randomly selected from each sector. The results show that board size and ethnic diversity have positive relationship with ROE while board independence has negative relationship. There is no significant relationship between managerial ownership, CEO duality and gender diversity on firm performance. The findings may provide some implications for future research regarding the effectiveness of board of directors towards firm performance.
\end{abstract}

Keywords: corporate governance, agency theory, board characteristics, firm performance, Malaysia

\section{Introduction}

The global business practices bring more attention to corporate governance but the problem is whether the board characteristics will influence firm performance is still become questionable. In Malaysia, there are firms that operating successfully but there are also firms that facing great losses while other conditions such as economic and politic remain constant. Therefore, this research aims to examine the factor influencing firm performance particularly the board of directors's characteristics.

The impact of corporate governance on firm performance has received considerable attention in the economic and finance literature in recent years. This increased attention has been motivated by the financial scandals that happened to the US economy in the early part of this decade such as Worldcom and Enron collapse. Despite the proliferation of studies, there is still much debate on the relationship between firm performance and boards of directors.

Malaysian Code on Corporate Governance (Revised, 2007) identified the principles and best practices of good governance and described optimal corporate governance structures and internal processes. It was first issued at 2000 as a milestone in corporate governance reform in Malaysia after Asian Financial Crisis 1997. It included duties and responsibilities of board of directors to influence firm performance for example reviewing and adopting a strategic plan, adequacy and the integrity of the company's internal control systems.

The motivation for focusing on the board of directors is as follows. First, corporate boards are one of the most important corporate governance mechanisms that monitor and advise management in carrying responsibility to protect shareholder interests (Fama \& Jensen, 1983). By including the board of directors' characteristics such as director's shareholding, gender, director size, director's race and directors' independence, it brings the new avenue for the researcher and regulators of the importance of board of directors's characteristics on the firm performance.

The primary purpose of this study is to provide empirical evidence concerning board of director's effects on firm performance for the 300 listed Malaysian companies. Specifically, this study investigates the determinant factors of firm performance and provides further evidence on the effect of board of directors' characteristics on firm performance.

The remainder of this paper is structured as follows. The next section provides the review of the previous literatures on the firm performance factors. The third section considers the research design employed for this 
study. The fourth section discusses the hypotheses development for this study and fifth section discusses analysis and findings of the study. The final section suggests possible limitations of the paper and concludes the study.

\section{Literature Review}

Previous studies have examined the firm performance factors but the study investigating the effect of board of directors' characteristics are still limited in numbers. In Malaysia, Hafizah (2006) conducted research on 622 Bursa listed financial and non-financial companies by using ROA. The findings showed that both insider and outsider shareholding do not have strong relationship with firm performance. She eventually recommended that high level of outsider ownership may reduce likelihood of financial fraud. Ali, Salleh and Hassan (2008) investigated the factor influencing firm performance by considering only non-financial companies based on the reason that the financial sector is subject to certain regulation and different from other industry. The study analyzed 1000 Bursa listed companies from 2000 to 2003 and proved positive relationship between managerial ownership and firm performance.

Druckeriv (1992) claimed that larger board possessed expertise in information and knowledge over smaller board and therefore improves the firm performance. The study claimed that larger board is tougher to manipulate other members and better monitoring on firm financial performance. They argued that larger board size has more external linkage, ability to extract critical resources such as funding, and expertise or experience in running the business and these attributes could lead to higher performance.

Fama and Jensen (1983) claimed that the management problem can be avoided with the adoption of outsiders in the board since they do not hold active role in the company except for their directorship which puts them in the best position to judge managerial decisions objectively. Higher proportion of outsiders on a board can better monitor and control the opportunistic behavior of the incumbent management, thus, minimizing the agency problem and maximizing shareholders' wealth. A study conducted by Sanda, Garba and Mikailu (2008) examined board independence on 205 Nigerian public listed companies from 1996 to 2004 by using only financial based measurement included ROA and ROE. The findings showed both positive effects of independent directors to firm performance. The results provide evidence that outside director representation is positively related with return on assets and on risk-adjusted stock returns by investigation on 300 Germany public listed companies.

Smith, Smith and Verner (2005) stated the advantages of having women in board where women directors may better understand particular market conditions than men, which may bring more creativity and quality to board decision making. Higher gender diversity on the board may generate a better public image of the firm and improve firm performance. Also, it is possible that the involvement of women in board explore external talent pool. Furthermore, the number of female top managers may positively influence the career development of women in lower positions by motivate them as inspiring model.

In context of Malaysia, Maran Marimuthu is one of the researchers who did survey on ethnic diversity and firm performance. She conducted research on 100 non-financial companies under Bursa from 2000 to 2006 measured by ROA to prove her hypothesis that ethnic diversity is positively associated with firm performance and found hypothesis accepted.

By reviewing all past studies in each board characteristics, it is show that the effect of each characteristic on firm performance is inconsistent, which mean that the effect can be positive or negative as each characteristic has its pros and cons. For example, the optimum firm size is remaining unclear; large firm size has better source of idea and knowledge but higher potential of communication conflict. Some studies proved large firm size positively associated with firm performance but some not.

In light of this recent evidence on the factors influencing firm performance, there is still avenue for areas of research where board of directors' characteristics can be expanded. As such, there is still a growing need to expand current literature and provide recent empirical evidence on other board of directors' characteristics that are still not widely researched in the past. Consequently, the objective of the study is to investigate the effect of board of directors' characteristics on firm performance for Malaysia public listed companies.

\section{Hypotheses Development}

Prior literature suggests that the presence of corporate governance mechanisms will increase the monitoring of management and reduce the incidence of mismanagement in the organization. Thus, effective corporate governance particularly the role of board of directors may improve the firm's value. According to Safieddine (2009), for good governance to take place there should be active participation of all parties, including the board 
of directors in fostering continuous improvements. Lack of strong corporate governance may jeorpadise the performance and internal control of the organization since all business functions are interrelated to each other.

Thus, this study goes deeply to examine the effect of board of directors' characteristics on ensuring the positive firm value continuously. Therefore, the hypotheses of this study were developed based on the board of directors' characteristics which include director's ownership, director size, CEO duality, director gender and ethnic diversity of the directors.

\subsection{Managerial Ownership}

Morck, Shleifer and Vishny (1988) found evidence that firm performance increase when the managerial ownership that is proxied by the director shareholder increase. Thus, if the managers hold more shares in the company, there will be less conflict of interest and the managers will be more likely to properly manage the business operation. Therefore, when more shares being held by the manager, the performance of the company will improved and at the end, will increase the company's profit. Thus, the following hypothesis is developed to show the relationship between firm performance and managerial ownership.

\section{$H_{1}$ : There is a positive relationship between firm performance and managerial ownership.}

\subsection{Board Size}

Previous studies claimed that as board size increase, conflict of interest will arise, as well as communication obstacles, which ultimately deteriorate firm performance. Coles, Naveen and Naveen (2008) indeed find evidence that larger firms, diversified firms, and firms that rely more on debt financing, will derive greater firm value from having larger boards. Thus, with the presence of more board size, proper management and control will be emphasized and help improve the company's financial and non financial performance. Therefore, the hypothesis can be described as follow:

\section{$\mathrm{H}_{2}$ : There is a positive relationship between firm performance and board size.}

\subsection{Board Independence}

Fama and Jensen (1983) explained that outside board of directors could strengthen the firm value by lending experienced and monitoring services and are supposed to be guardians of the shareholders' interest via monitoring and control. Beasley (1996) explained that independent directors hold better judgment and fair representation of shareholders' interest, suitability as a reliable governing mechanism and their potential ability to concentrate on ensuring the maximization of shareholder value. Therefore, greater board independence will ensure high value to the firm and thus, the following hypotheses is as follows:

\section{$H_{3}$ : There is a positive relationship between firm performance and board independence.}

\subsection{CEO Duality}

Separation of role is to ensure the balance of power of the two designations as well as to avoid conflict of interest to arise. The absence of separation of decision management and decision control, the board will be unable to effectively monitor and evaluate the CEO (Mary, 2005). The CEO is more likely to use his power as board chairman to select directors of his favor. In addition, a board controlled by the CEO is likely lead to more agency problems and poor performance. Thus, CEO duality invites more conflicts and reduces firm performance and thus, the following hypothesis is developed:

\section{$\mathrm{H}_{4}$ : There is a negative relationship between firm performance and CEO duality.}

\subsection{Gender Diversity}

Verner (2006) stated that woman directors may better understand particular market condition than man, which brings more creativity and quality to board decision making. Larger gender diversity may generate a better public image of the firm and improve firm performance. Therefore, the following hypothesis is constructed:

\section{$\boldsymbol{H}_{5}$ : There is a positive relationship between firm performance and gender diversity.}

\subsection{Ethnic Diversity}

Hambrick, Cho and Chen (1996) discussed advantages of having ethnic diversity in board. Ethnic diversity broadens knowledge, idea and experience through the range of information resources of different cultural background among the board members. An organization with high level of cultural heterogeneity in management able to share ideas and reach ultimate decision based on the various thinking and thus, will improve management performance through a common consensus among the multiracial group of the boards. Thus, large ethnic diversity 
may improve firm performance by sharing and reaching ultimate decision and the following hypothesis is developed to show the relationship.

\section{$H_{6}$ : There is a positive relationship between firm performance and ethnic diversity.}

\section{Research Design}

\subsection{Unit of Analysis}

The unit analysis is the annual reports for the year 2011 of companies listed on Bursa Malaysia. The prime source is the company's annual report itself. This is consistent with prior studies that utilized annual reports as the main source of data (Zubaidah, Nurmala \& Jusoff, 2009; Malimuthu, 2009; Hashim \& Devi, 2010).

\subsection{Sampling Design and Data Collection}

For this study, stratified random sampling technique is used to obtain a sample of public listed companies on the Bursa Malaysia by sectors. Each sector represents a particular industry as classified by the Bursa Malaysia and, wherever necessary, some sectors are combined due to small observations. Consequently, a total of ten sectors emerged and used, namely; construction, consumer product, finance, hotel, industrial product, mining, plantation, properties, technology and trading/service. This sampling technique permits a better understanding of the companies' practices within various sectors in the Bursa Malaysia. The rationale of mixing those sectors is to ensure that all industries are included. A final list of sectors is as per Table 1.

Table 1. Demography of the respondents

\begin{tabular}{lll}
\hline Industry & Total Listed Companies & Percentage (\%) \\
\hline Construction & 15 & 5 \\
Consumer Product & 50 & 16.67 \\
Finance & 10 & 3.33 \\
REIT & 10 & 3.33 \\
Industrial Product & 75 & 25 \\
Mining & 1 & 0.33 \\
Plantation & 9 & 3 \\
Properties & 40 & 13.33 \\
Technology & 30 & 10 \\
Trading \& Service & 60 & 20 \\
Total & $\mathbf{3 0 0}$ & $\mathbf{1 0 0}$ \\
\hline
\end{tabular}

\subsection{Operationalization of Variables}

This study used multiple regression analysis by modeling ROE as a function of explanatory variables. The independent variables are comprised of managerial ownership, board size, board independence, CEO duality, Gender and Race. Specifically, the ROE model used in this study is consistent from prior studies (Zubaidah et al., 2009; Hashim \& Devi, 2010). The ROE model for this study is as follows:

$$
R O E=\alpha_{0}+\alpha_{1} \text { OwnS }+\alpha_{2} \text { Bsize }+\alpha_{3} \text { Bind }+\alpha_{4} \text { Dual }+\alpha_{5} \text { Gend }+\alpha_{6} \text { Race }+\varepsilon
$$

Table 2 summarizes the operationalization of the dependent and independent variables tested in this study.

Table 2. Summary of the Operationalisation of Variables

\begin{tabular}{ll}
\hline Variables & Operational Measures \\
\hline Managerial ownership (OwnS) & The proportion of the number of shares hold by BOD to the total shares in the company \\
Board size (Bsize) & Total number of directors in the company \\
Board Independence (Bind) & The proportion of non-executive directors to the total number of directors \\
CEO duality (Dual) & Assigned as 1 for a CEO is not a chairman and 0 for CEO is also a chairman \\
Gender diversity (Gend) & The proportion of female directors to the total number of directors \\
Ethnic diversity (Race) & The proportion of directors excluded majority race to the total number of directors \\
\hline
\end{tabular}

\section{Analysis and Findings}

\subsection{Descriptive Analysis}

Table 3 presents the value of mean and standard deviation of all the variables in the study. The analysis is based on sample size of 300 firms and the annual reports selected and analyzed in year of 2011. By referring to the 
result, mean for all variables range between 6.73 to 45.11 and the standard deviation falls within range of 2.0 to 17.72. ROE's average percentage is 6.73 with standard deviation of 11.27 , signified the positive performance of Malaysia firms.

Table 3. Descriptive Analysis

\begin{tabular}{|c|c|c|c|}
\hline Variables & Mean & & Standard Deviation \\
\hline Managerial Ownership & 13.79 & & 17.72 \\
\hline Board Size & 7.35 & & 1.96 \\
\hline Board Independence & 45.11 & & 12.94 \\
\hline Gender Diversity & 9.82 & & 12.00 \\
\hline Ethnic Diversity & 24.02 & & 15.82 \\
\hline Return On Equity & 6.73 & & 11.27 \\
\hline Variables $(N=300)$ & Category & Frequency & Percentage \\
\hline \multirow{2}{*}{ CEO Duality } & Yes & 54 & 18 \\
\hline & No & 246 & 82 \\
\hline
\end{tabular}

\subsection{Correlation Analysis}

The objective of the analysis is to identify whether there is relation among variables and to detect if multicollinearity problem exists. The multicollinearity is a phenomenon where two or more variables are highly correlated. High degree of multicollinearity indicated bias relation between two variables and it may affect accuracy of multiregression test result. The problem exists if independent variables are highly correlated at each other with correlation exceeding 0.9 according to Tabachnick and Fidel (2007). However, none of the variables found to be more than 0.5. The highest correlation is between the two variables which are CEO duality and firm performance (ROE) that is 0.302 which suggest that multi-collinearity is not a serious problem that would jeopardize the regression results (Tabachnick \& Fidell, 2007).

Table 4. Pearson Correlation

\begin{tabular}{|c|c|c|c|c|c|c|c|}
\hline & Owns & Bsize & Bind & CEOD & Gend & Race & ROE \\
\hline OwnS & 1 & $-0.142\left(^{*}\right)$ & -0.051 & -0.020 & 0.062 & $-0.148^{*}$ & -0.009 \\
\hline Bsize & & 1 & $-0.338^{* *}$ & $0.119\left(^{*}\right)$ & 0.081 & $0.210^{* *}$ & $0.228^{* *}$ \\
\hline Bind & & & 1 & -0.051 & -0.092 & 0.087 & $-0.121^{*}$ \\
\hline CEOD & & & & 1 & 0.094 & 0.041 & $0.302^{* *}$ \\
\hline Gend & & & & & 1 & -0.040 & 0.094 \\
\hline Race & & & & & & 1 & $-0.148^{*}$ \\
\hline ROE & & & & & & & 1 \\
\hline
\end{tabular}

Note: ${ }^{*}{ }^{* *}$ significant at 5\% level (2-tailed) and 1\% level (2-tailed). OwnS = managerial ownership, the percentage of share hold by BOD as opposed to firm's total shares; Bsize: Board size, total amount of BOD in a firm; Bind: Board independence, percentage of independent directors in BOD; CEOD: CEO duality, YES represents board chairman is also CEO of the firm and NO represents not CEO of firm; Gend: Gender diversity, the percentage of female directors in BOD; Race: Ethnic diversity, the percentage of non-majority race in BOD; ROE: Return On Equity, measured by divided earnings before interest \& tax with total owner equity.

\subsection{Multivariate Analysis}

Table 5 shows the multivariate analysis. The findings found no support for H1 (managerial ownership). It can be said that the directors shareholding do not give any effect to the firm performance. This result contradicts with local studies such as Ali et al., (2008), Hafizah (2006) and Radziah, Ibrahim and Pok (2009) that came out with positive relationship between managerial ownership and firm performance, given the reason that the agency problem likely to be reduced if BOD hold company shares, thus they will work for the company in order to increase share value, instead of personal interest. However, the result is consistent with Demsetz (1985) in his study of 500 US public listed companies. His study concluded that there is actually no relation between managerial ownership and firm performance because corporate compensation and incentive system with effective control will offset agency problem instead of managerial ownership. Corporate compensation and incentive schemes included monetary such as bonus or non-monetary such as vacation and insurance had proved more effectively controlled agency problem that granted shares to BOD. 
The results support $\mathrm{H} 2$ and $\mathrm{H} 6$, and provide evidences that board size and ethnic diversity are significantly associated with firm performance. The results are consistent with Salleh, Iskandar and Rahmat (2005).

It shows that board size is negative and significantly associated with firm performance. This was initially supported earlier, where Bsize has a positive and significant relationship with firm performance and is consistent with Salleh et al. (2005). The findings support H2 (board size) and provide evidence that larger board size tends to ensure that the management control of the company is strong. Consequently, it generates positive influence on the managers to mitigate the conflict of interest and personal interest and thus, able to ensure that the managers are strive to work for the betterment of firm performance.

Table 5. Multiple Regression Analysis

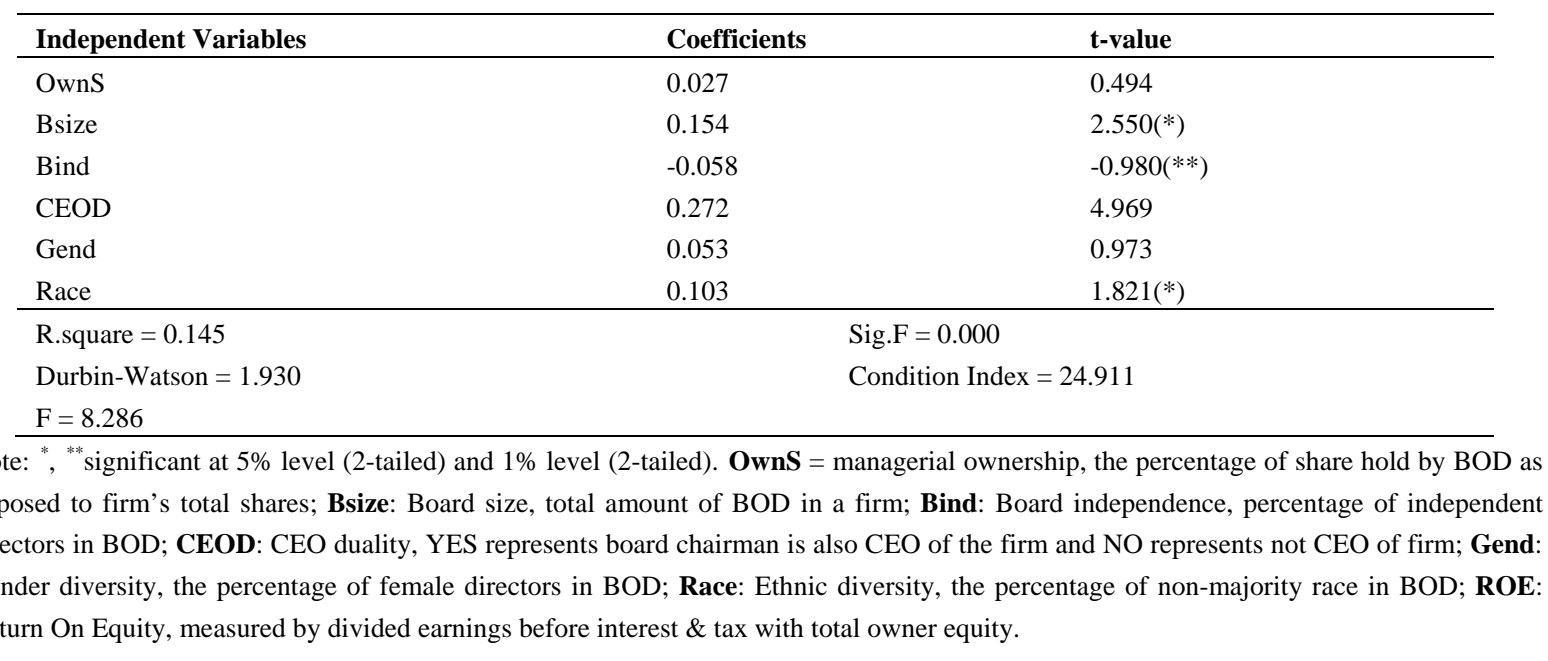

H3 (board independence) has a significant negative association with firm performance and subsequently contradict with the expected hypotheses. The finding provides no evidence that companies having more independence directors able to increase firm value because there is no personal interest being exercised. The finding is contradict with Johari, Salleh, Jaafar and Hassan (2008) and Saat, Karbhari, Heravi and Nassir (2011) that found positive effect on firm performance due to more outside directors in a board will offset agency problem, think objectively since they are not hold executive position in company and able to buy in external expertise which will yield company performance.

From the findings, more independent directors existed in a board will more likely deteriorate firm performance. It can be explained by most of outside directors in practice of firms in Malaysia are directors from overseas, majority from Singapore and US and they are not well capable of cope with local business environment, as well as local business culture. Therefore, inside directors play better role in improve firm performance due to they are more familiar with local business and manage the company, thus take action which is better for the company than outside directors do.

The findings also find no support for H4 (CEO duality) and H5 (gender diversity). This result might be due to the practice of Malaysia companies where the CEO should be separated from the chairman. Thus, since most of the firms are separated the person who holding the CEO position and chairman position, the result showed the insignificant results. The finding is inconsistent with Ponnu (2008) and Zubaidah, et al. (2009) that CEO duality has no effect on firm performance. Furthermore, the reasons of insignificant finding can be caused by the small portion of firms that adopted CEO duality in Malaysia. CEO duality is not a common practice in Malaysia since MCCG 2007 suggested separation of role of board chairman and CEO. Majority of firms with CEO duality in Malaysia are family business but companies listed in Bursa only have small portion of family business. Based on Table 3, the firms with CEO duality only consisted of 18 percent of total sample, therefore not strong enough to present significant effect in this study.

Hypothesis H5 suggested gender diversity has positive effect on firm performance. However the result finds no relation between firm performance and gender diversity. It can be best explained that the increasing or decreasing of female in BOD would not give significant effect to firm performance. The result is contradict to Amran (2011) but consistent with the result found by Marimuthu (2009), given the reason that there is no actual effect of gender diversity to firm performance because it is depending on the country and corporate culture. 
Hypothesis H6 commented that ethnic diversity has positive effect on firm performance is accepted in this study even it shows negative relation to firm performance in correlation analysis. This is to explain that larger ethnic diversity on the board yield to positive firm performance. The finding is consistent with Marimuthu (2009) where he stated that multi-racial board had positively affected firm performance.

The finding can be explained by Malaysia as a multi-racial community, people are get used to live and interact with another from different ethnic background. Therefore in management, it is less likely to cause conflict or miscommunication. Upper Echelon Theory suggested that high degree of demographic diversity in board may combine different idea; opinion and expertise thus generate better strategies. The theory applied to situation in Malaysia firms.

\section{Conclusion}

The present sought to explain the relationship between board's characteristics with the firm performance. It is found that there is a negative relationship between board size and CEO duality with the firm performance while board independence and ethnic diversity are negatively related with the firm performance. The results of the study are mostly consistent with the previous studies and it shows that the importance of board's characteristics should be emphasized in order to improve the firm performance. Following the guideline by the MCCG, it will be more of superlative guidance for the firm to maintain their firm performance by managing their board characteristics.

However, there are possible limitations in relation to the research design of this study. The study based on the cross-sectional study which is concern about the single year period may not provide more generalized result. Furthermore, the explanatory independent variable used in this study are very limited which is subjected to the board's characteristics only may not be able to provide evidence of other possible factors that may affect firm performance.

Therefore, in future study, it is suggested to consider the longitudinal study which comprise of more than one year period in order to get more generalized results. It is also suggested to include other mechanisms of corporate governance such as ownership structure in order to examine the overall influence of corporate governance on firm performance.

\section{References}

Ali, S. M., Salleh, N. M., \& Hassan, M. S. (2008). Ownership structure and Earnings Management in Malaysia Listed Companies. Asian Journal of Business and Accounting, 1(2), 89-116.

Amran, N. A. (2011). Corporate Governance Mechanisms and Company Performance: Evidence from Malaysian Companies. International Review of Business Research Papers, 7(6), 101-114.

Beasley, M. S. (1996). An Empirical Analysis of the Relation Between the Board and Director Composition and Financial Statement Fraud. The Accounting Review, 71(4), 443-65.

Coles, J. L., Naveen, D. D., \& Naveen, L. (2008). Boards: Does one size fit all? Journal of Financial Economies, 87(2), 329-356. http://dx.doi.org/10.1016/j.jfineco.2006.08.008

Druckeriv, P. (1992). Corporate Governance after Enron and WorldCom Applying Principles of Results-Based Governance. Working Paper presented at Insight Conference on Corporate Governance.

Fama, E. F., \& Jensen, M. C. (1983). Separation of ownership and control. Journal of Law and Economics, 26(2), 301-325. http://dx.doi.org/10.1086/467037

Hambrick, D. C., Cho, T. S., \& Chen, M. (1996). The influence of top management team heterogeneity on firms' competitive moves. Administrative Science Quarterly, 41, 659-684. http://dx.doi.org/10.2307/2393871

Hashim, H. A., \& Devi, S. S. (2010). Corporate Governance, Ownership Structure and Earnings Quality: Malaysian Evidence. Working Paper, University Malaya.

Johari, N. H., Salleh., N. M., Jaafar, R., \& Hassan, S. M. (2008). The Influence of Board Independence, Competency and Ownership on Earnings Management in Malaysia. International Journal of Economics and Management, 2(2), 281-306.

Marimuthu, M. (2009). Ethnic and Gender Diversity in Board Of Directors and Their Relevance to Financial Performance of Malaysian Companies. Journal of Sustainable Development, 2(3), 139-148.

Mary, A. C. (2005). The Relationship Between Chief Executive Officer Duality and Subsequent Corporate Financial Performance. Working Paper, Capella University. 
MCCG. (2007). Malaysian Code on Corporate Governance. Report on Corporate Governance, Securities Commission, Kuala Lumpur.

Mohd Saat, N. N., Karbhari, Y., Heravi, S., \& Nassir, A. M. (2011). Effective Oversight Roles of Board of Directors - The Case of Listed Firms on Bursa Malaysia. World Review of Business Research, 1(1), 231-245.

Morck, R., Shleifer, A., \& Vishny, R. W. (1988). Management Ownership and Market Valuation: An Empirical Analysis. Journal of Financial Economies, 20, 293-315. http://dx.doi.org/10.1016/0304-405X(88)90048-7

Ponnu, C. H. (2008). Corporate Governance Structures and The Performance of Malaysian Public Listed Companies. International Review of Business Research Papers, 4(2), 217-230.

Radziah, M., Ibrahim, M. K., \& Pok, W. C. (2009). Earnings Quality Attributes and Performance of Malaysian Public Listed Firms. Available at SSRN: http://ssrn.com/abstract=1460309

Safieddine, A. (2009). Islamic financial institutions and corporate governance: new insights for agency theory. $\begin{array}{llll}\text { Corporate } \quad \text { Governance: An International Review, 17(2), } & \text { 142-158. }\end{array}$ http://dx.doi.org/10.1111/j.1467-8683.2009.00729.x

Salleh, N. M., Iskandar, T. M., \& Rahmat, M. M. (2005). Earnings Management and Board Characteristics: Evidence from Malaysia. Jurnal Pengurusan, 24, 77-103.

Sanda, A. U., Garba, T., \& Mikailu, A. S. (2008). Board Independence and Firm Financial Performance: Evidence from Nigeria. Working Paper, Usmano Danfodiyo University.

Smith, N., Smith, V., \& Verner, M. (2005). Do Women in Top Management Affect Firm Performance? A Panel Study of 2500 Danish Firms. Available at SSRN: http://ssrn.com/abstract=780910

Tabachnick, B. G., \& Fidell, L. S. (2007). Using Multivariate Statistics (5th ed.). USA: Pearson Education Inc.

Zubaidah, Z. A., Nurmala, M. K., \& Jusoff, K. (2009). Board Structure and Corporate Performance in Malaysia. International Journal of Economics and Finance, 1(1), 150-164. 